\title{
Antioxidative and Neuroprotective Activities of the Pre-Germinated Brown Rice Extract
}

\author{
Rungtip Soi-ampornkul, Sarawut Junnu, Surin Kanyok, Sompong Liammongkolkul, \\ Wanphen Katanyoo, Supranee Umpornsirirat
}

Department of Biochemistry, Faculty of Medicine Siriraj Hospital, Mahidol University, Bangkok, Thailand.

Email:sirsm@mahidol.ac.th

Received September $23^{\text {rd }}, 2011$; revised November $3^{\text {rd }}, 2011$; accepted November $12^{\text {th }}, 2011$

\begin{abstract}
We evaluated the effects of pre-germinated brown rice extract (PGBR ex) with enhanced levels of GABA on proliferation and apoptosis of neuronal SK-N-SH cells line. Firstly, we used HPLC methods to study the level of $\gamma$-aminobutyric acid (GABA) in all rice extracts. We found that the concentration of GABA in the PGBR ex were 3 and 8 times higher than the GABA concentration in non-germinated brown rice (BR ex) and white rice (WR ex) compared with the standard GABA respectively. Next we study the protective effects of brown rice extract by investigating various methods, we found that the effects of dose-dependent study by treated with PGBR ex, BR ex and WR ex at $(0-4000 \mu \mathrm{g} / \mathrm{ml})$. The data from MTT assay showed that the higher concentration of all rice extracts were not induced toxicity to SK-N-SH cells. To test the protective effect by study the viability of SK-N-SH cells. These results showed that PGBR ex and BR ex can protect cells by significantly increase cells survival up to $29.3 \% \pm 0.01 \%$ and $13.4 \% \pm 0.07 \%(p<0.05)$ but not WR ex comparable with $150 \mu \mathrm{M} \mathrm{H}_{2} \mathrm{O}_{2}$ alone which caused cells death $>56.9 \% \pm 0.02 \%(p<0.05)$, compared with untreated cells (control). Next study we test the effect of cells apoptotic by ROS assay and DNA fragmentation. The results showed that PGBR ex were definitely decrease the amount of ROS formation and had a little of DNA ladders comparable with condition that induced by $150 \mu \mathrm{M} \mathrm{H}_{2} \mathrm{O}_{2}$. Our data indicating that PGBR ex with enhanced levels of GABA effectively inhibit SK-N-SH cells proliferation and apoptosis. These present results suggest that intake of PGBR and BR instead of WR is effective to protect cell proliferation and apoptosis which may be useful nutritional to prevent neuronal cells from neurodegenerative disease.
\end{abstract}

Keywords: Pre-Germinated Brown Rice; SK-N-SH Cells; Antioxidant; GABA; Apoptosis; DNA Fragmentation

\section{Introduction}

Rice is a major cereal food and is a dietary staple world wide, especially in Asian countries. Rice seeds and rice germ contain fiber and several kinds of antioxidants, such as ferulic acid, phytic acid, tocopherols, and oryzanols. Brown rice is a rice seed from which only the hull is removed. Recently, we found that pre-germinated brown rice contains a much higher concentration of esential amino acids, such as lysine, isoleucine, methionine, than conventional brown rice, and over 13 times the amount of $\gamma$-aminobutyric acid (GABA) [1,2]. Pre-germinated brown rice (PGBR) is brown rice, which has been soaked in water for up to a day and had a germ of approximately $1 \mathrm{~mm}$ long. During germination, nutrients in the brown rice change drastically. Nutrients that increase in content include $\gamma$-amirobutyric acid (GABA), dietary fiber, inositols, ferulic acid, phytic acid, tocotrienols, magnesium, potassium, zinc, $\gamma$-oryzanol, and prolylendopeptidase in- hibitor. According to Kenichi, germinated brown rice contained more total ferulic acid (126\%), total dietary fiber $(145 \%)$, soluble dietary fiber $(120 \%)$ and insoluble dietary fiber (150\%) compared to the brown rice [3].

Free radicals have been found to be crucial because they can cause several severe diseases such as cancer, cardiovascular and cell degeneration [4]. This damage results from the imbalance between antioxidants and free radicals in the body [5]. Thus efforts are being expended in the search for substances that can prevent and inhibit the activity of free radicals. An important source of antioxidants is daily vegetables and fruits [6]. Oxidative stress induced cell damage has been shown to be involved in neurodegenerative diseases such as Alzheimer's disease, Parkinson's disease, and stroke [7]. The damage is mediated by reactive oxygen species (ROS), mainly superoxide anion $\left(\mathrm{O}_{2}^{-}\right)$and hydrogen peroxide $\left(\mathrm{H}_{2} \mathrm{O}_{2}\right)$. Accumulation of ROS in neuronal cells results in lipid peroxidation, protein and DNA damage, and finally cell death [8]. Sev- 
eral studies revealed that ROS can be inhibited by antioxidants [9].

The neuroprotective activity of various natural extracts has been reported in the literature [10]. The water extract of Curcuma longa reduces rat pheochromocytoma PC12 cell death induced by pyrogallol and $\mathrm{H}_{2} \mathrm{O}_{2}$ [11]. The water-soluble extracts of the seed of Celastrus paniculatus have neuroprotective effects against glutamate-induced toxicity in embryonic rat forebrain neuronal cells [12]. Relevant studies associated with rice include the observations that aqueous-ethanol extracts of rice bran exhibited antioxidative properties feruloyl-myoinositols present in rice bran inhibited phorbolester-induced super-oxide anion generation in HL-60 cells [13] the cyaniding 3-O$\beta$-D-glucoside isolated from pigmented rice scavenged superoxide anions but not hydroxyl radicals [14] a quinolone alkaloid isolated from the pigmented rice exhibited antioxidative activity [15] dietary pigmented rice protected against lipid peroxidation in the rat kidneys [16] cyanidin and malvidin isolated from a pigmented rice inhibited the growth of leukemia cells [17] pigmented rice suppressed reactive oxygen species in an in vitro assay [18] and protocatechuic acid methyl ester isolated from black rice inhibited the enzymatic activity of tyrosinase. Recently, Choto-san was shown to act as an antioxidant and neuroprotective agent against oxidative damage in NG108-15 cells [19]. Among them, rice bran is a by-product of the rice milling process and contains various antioxidant factors showing beneficial effects on human health. As well known antioxidants in rice bran, tocopherols, tocotrienols, oryzanols (ferulate esters of triterpene alcohols) are isolated from fat-soluble extracts of rice bran and they have potent hypocholesterolemic and antitumor properties [20]. However, to date, no attempts have been made to investigate the effects of brown rice extracts containing high levels of GABA on proliferation and apoptosis of neuronal cells. The antioxidants of the water-soluble extract of rice bran have been poorly analyzed. In the present study, we investigated the antioxidative and neuroprotective activity of the brown rice extracts with enhanced GABA level (PGBR ex) were tested comparable with BR ex and WR ex against $\mathrm{H}_{2} \mathrm{O}_{2}$-induced oxidative damage in neuroblastoma SK-N-SH cells and the toxicity of the rice bran extracts on these cells by using assay systems for cells survival, ROS generation and DNA fragmentation. The significance of this finding is discussed from the viewpoint of the preventive role of the rice bran against oxygen radical-related chronic diseases.

\section{Materials and Methods}

\subsection{Cells Culture}

The human neuroblastoma SK-N-SH cells line was obtained from the ATCC (Rockville, MD, USA) and main- tained in minimum essential medium (Life Technology, Inc.) containing $2 \mathrm{mM} \mathrm{L}$-glutamine in a humidified incubator at $37^{\circ} \mathrm{C}$ and $5 \% \mathrm{CO}_{2}$. The medium was supplemented with $10 \%$ fetal bovine serum, $1 \mathrm{mM}$ sodium pyruvate, $0.1 \mathrm{mM}$ minimal essential medium nonessential amino acids (Life Technology, Inc.), 100 units/ml penicillin, and $100 \mathrm{mg} / \mathrm{ml}$ streptomycin (Biofluids, Rockville, $\mathrm{MD})$. Cells were plated at $5 \times 10^{5}$ cells $/ \mathrm{ml}$ were cultured in 96 well plates (for Reactive Oxygen Species (ROS) formation and for cell viability (MTT assay). Cell were plated at $1 \times 10^{6}$ cells $/ \mathrm{ml}$ on 6 well plates for DNA fragmentation then maintained in serum free optimal minimal modified Eagles medium (MEM) supplemented with Fetal bovine serum (Invitrogen, Carlsbad, CA). Cultures were maintained for $24 \mathrm{~h}$ before treatments.

\subsection{Preparation of Brown Rice Extracts}

Pre-germinated brown rice (Oryza sativa L.) was supplied by Innofood (Thailand) Co., Ltd. in Pratumthani and was germinated by soaking in the following solutions at $25^{\circ} \mathrm{C}-26^{\circ} \mathrm{C}$ in the dark for $72 \mathrm{~h}$ : was air dried, frozen in liquid nitrogen pre-germinated brown rice extracts were prepared as previously described [10] Briefly, the pregerminated brown rice (PGBR), brown rice (BR), polish rice or white rice (WR) were ground with a mortar and pestle, and then added with distilled water mix with Vortex for $10 \mathrm{~min}$ and then kept in water bath at $70^{\circ} \mathrm{C}$ for 30 $\min$. The samples were centrifuged at $15,000 \mathrm{rpm}$ at $4^{\circ} \mathrm{C}$ for $30 \mathrm{~min}$, and the supernatants were collected, passed through filters with $0.45 \mu \mathrm{m}$ pores, and used as extracts.

\subsection{Effect of Brown Rice Extracts on Cell Viabilities of SK-N-SH Cell Lines}

To determine the influence of brown rice extract on cell viability which induced by $150 \mu \mathrm{M} \mathrm{H}_{2} \mathrm{O}_{2}$. Cells were plated $5 \times 10^{5}$ cells $/ \mathrm{ml}$ in 96-well plates (Falcon, Germany) in medium supplemented with $10 \%$ fetal bovine serum and penicillin/streptomycin. After additions by treated with in- creasing concentrations of brown rice extract $(0$ $4000 \mu \mathrm{g} / \mathrm{ml}$ ) at $37^{\circ} \mathrm{C}$ for $3 \mathrm{~h}$ and further added with 150 $\mu \mathrm{M} \mathrm{H}_{2} \mathrm{O}_{2}$ in culture incubation at $37^{\circ} \mathrm{C}$ for $24 \mathrm{~h}$ as indicated. Viabilities of the cells were assay by the MTT [3-(4,5-dimethylthiazol-2-yl)-2,5diphenyltetrazolium bromide] method, MTT solution was added at a final concentration of $0.5 \mathrm{mg} / \mathrm{ml}$ at $37^{\circ} \mathrm{C}$ for $3 \mathrm{~h}$ incubation. Then solubilize solution (DMSO) was then added, the plates were shaken for $10 \mathrm{~min}$ and absorbance was read at $570 \mathrm{~nm}$ in a microplate reader.

\subsection{Assay for Reactive Oxygen Species Formation}

Detection of intracellular reactive oxygen species (ROS). The production of intracellular reactive oxygen species 
was estimated by using a fluorescent probe, 2',7'-dichlorofluorescein diacetate (DCFH-DA) [21]. DCFH-DA is transported across the cell membrane and hydrolyzed by intracellular esterases to form nonfluorescent $2^{\prime}, 7^{\prime}$-dichloro fluorescein $(\mathrm{DCFH})$, which is then rapidly converted to highly fluorescent $2^{\prime}, 7^{\prime}$-dichlorofluorescein (DCF) in the presence of reactive oxygen species. The DCF fluorescence intensity is believed to be parallel to the amount of reactive oxygen species formed intracellular. To study the free radical scavenging effect of Brown rice extracts (rice extract at final concentration $2000 \mu \mathrm{g} / \mathrm{ml}$ ) was added $3 \mathrm{~h}$ before added with $150 \mu \mathrm{M} \mathrm{H}_{2} \mathrm{O}_{2}$ to the culture and incubated at $37^{\circ} \mathrm{C}$ for $24 \mathrm{~h}$. To determine the amounts of ROS induced by $\mathrm{H}_{2} \mathrm{O}_{2}$, DCFH-DA ( $50 \mu \mathrm{M}$ final concentration in DMSO) was added to the cells culture and then incubated at $37^{\circ} \mathrm{C}$ for $2 \mathrm{~h}$. The production of reactive oxygen species was measured immediately by microplate reader using excitation and emission at $485 \mathrm{~nm}$ and a $530 \mathrm{~nm}$.

\subsection{Effect of Brown Rice Extracts on Apoptosis and DNA Fragmentation by DNA Extraction and Agarose Gel Electrophoresis}

Cultured cells were prepared at $1 \times 10^{6}$ cells/well in 6 well plates. Rice extracts were added into the cultures at $2000 \mu \mathrm{g} / \mathrm{ml}$ and cultured at $37^{\circ} \mathrm{C}$ for $3 \mathrm{~h}$ and further added with $150 \mu \mathrm{M} \mathrm{H}_{2} \mathrm{O}_{2}$ in culture incubation at $37^{\circ} \mathrm{C}$ for $24 \mathrm{~h}$ then cells were collected. Genomic DNA was extracted using the Apoptotic DNA Ladder Kit, (Roche Applied Science, Mannheim, Germany) with slightly modification. In brief, cells were washed twice with ice cold $1 \times$ PBS, then $200 \mathrm{uL}$ binding/lysis buffer was added and mixed immediately. After holding for $10 \mathrm{~min}$ at $22^{\circ} \mathrm{C}, 100 \mu \mathrm{L}$ of $100 \%$ isopropanol was added and the solution was vortexed for $10 \mathrm{sec}$. The lysate was run through the column then washed twice with washing buffer. DNA was eluted with $200 \mu \mathrm{L}$ of pre-warmed $\left(70^{\circ} \mathrm{C}\right)$ elution buffer and concentrated with a speedvac. Extracted DNA was subjected to gel electrophoresis, and the image was captured with GelDoc ${ }^{\mathrm{TM}}$ EQ (Bio-Rad Laboratories, Ltd. Hercules, CA).

\subsection{Statistical Analysis}

The results were expressed as mean \pm SEM of triplicate assays. The statistical comparison between control and treated experimental groups were carried out using Student's $t$-test. $P$-value less than 0.05 were considered to be significantly different.

\section{Results and Discussion}

\subsection{The Cytotoxicity of Pre-Germinated Brown Rice Extract on SK-N-SH Cells}

First, we attempted to establish the doses dependent of the brown rice extract, the cytotoxicity of brown rice extract on human neuronal SK-N-SH cells was observed. PGBR ex, BR ex and WR ex were applied in culture by increasing concentrations $0-4000 \mu \mathrm{g} / \mathrm{ml}$ to $\mathrm{SK}-\mathrm{N}-\mathrm{SH}$ cells for $24 \mathrm{~h}$. We found that the data of cells survival showed that std. GABA up to $96.4 \pm 0.052(p>0.48)$, PGBR ex $98.9 \pm 0.032(p>0.30)$, BR ex $96.3 \pm 0.039(p$ $>0.39)$ and WR ex $95.3 \pm 0.037(p>0.25)$, respectively. The data of viability cells had no significantly decrease cell survivals which had no toxicity affect on human neuronal SK-N-SH cells (Figure 1). However, treated with $150 \mu \mathrm{M} \mathrm{H}_{2} \mathrm{O}_{2}$ alone caused cells death $>56.9 \% \pm$ $0.02 \%(p<0.05)$ compared with control indicating at this concentration $\mathrm{H}_{2} \mathrm{O}_{2}$ had toxicity to $\mathrm{SK}-\mathrm{N}-\mathrm{SH}$ cells. (data not shown) Similar to Chan-Ho Oh and Suk-Heung Oh had tested the effect of the brown rice extracts on the viability of Hela cells, by treated cells with the brown rice ex extracts $2000 \mu \mathrm{g} / \mathrm{ml}$ in cultured, the viability of the cells was assayed. Their results had shown that brown rice extracts also had no effects on the retardation of HeLa cell proliferation.

\subsection{PGBR Ex Inhibit the Neuronal SK-N-SH Cell Death Induced by $\mathrm{H}_{2} \mathrm{O}_{2}$}

Next we tested the protective effects of the brown rice extracts on the viability of SK-N-SH cells, cells were pretreated with the PGBR ex, BR ex and WR ex at $2000 \mu \mathrm{g} / \mathrm{ml}$ and then treated with $150 \mu \mathrm{M} \mathrm{H}_{2} \mathrm{O}_{2}$. These results showed that PGBR and BR ex can protect cells. The cells survival significantly increase up to $29.3 \% \pm 0.01 \%$ and $13.4 \% \pm$ $0.07 \%(p<0.05)$, but not WR ex comparable with 150 $\mu \mathrm{M} \mathrm{H}_{2} \mathrm{O}_{2}$ treated alone which caused cells death $>56.9 \pm$ $0.02 \%$ compared with control (Figure 2). PGBR ex contains approximately 13 times of GABA and the amount of

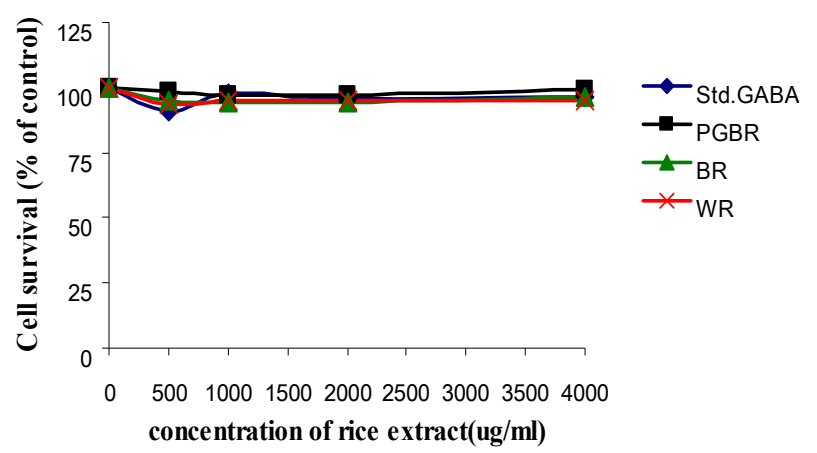

Figure 1. Effect of brown rice extract on the viability of neuronal SK-N-SH cells. Cells $\left(5 \times 10^{5}\right.$ cells $\left./ \mathrm{ml}\right)$ were incubated with increasing concentrations of brown rice extracts; PGBR, BR and WR at $0-4000 \mu \mathrm{g} / \mathrm{ml}$. Cultures were incubated at $37^{\circ} \mathrm{C}$ for $24 \mathrm{~h}$. The cytotoxicity of brown rice extract was measured using MTT assay, as described in Materials and methods. Results are expressed as percentages of the control value (untreated cells) and data shown are means \pm S.E.M of three replicate experiments. 


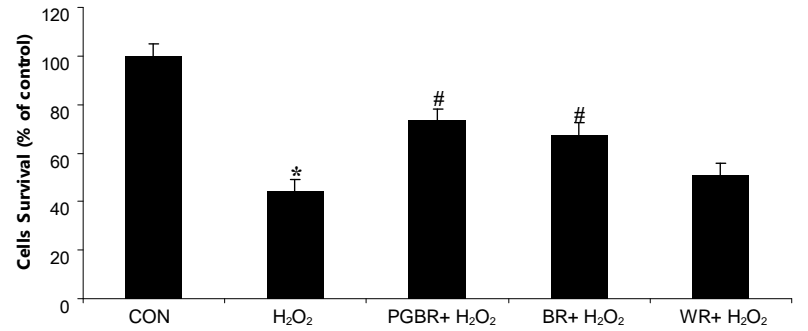

Figure 2. Protective effects of brown rice ex upon neuronal $\mathrm{SK}-\mathrm{N}-\mathrm{SH}$ cell death induced by $150 \mu \mathrm{M} \mathrm{H}_{2} \mathrm{O}_{2}$. Cells were prepared at $5 \times 10^{5}$ cells $/ \mathrm{ml}$. The extracts of PGBR, BR and WR were added into the cultures. The viability of the cells was assayed by the MTT assay. Results are expressed as percentages of the control value. The data shown are means \pm SEM of three experiments performed in triplicate. $*=P<$ 0.05 compared to the untreated control; \# $=P<0.05$ compared to the $150 \mu \mathrm{M} / \mathrm{ml} \mathrm{H}_{2} \mathrm{O}_{2}$-treated group.

oryzanol in polished rice. Ferulic acid ester is one of the main components of oryzanol, a phytosterol derived from rice bran. Previous reports have hypothesized that oxidative stress is one of the mechanisms of $\mathrm{A} \beta$-induced neurotoxicity. In vitro studies have shown that $\beta$-tocopherol, a representative antioxidant, inhibits $\mathrm{A} \beta$-induced neuronal cell death and lipid peroxidation [22]. Ferulic acid also possesses free radical scavenging activity and reduces peroxidative damage [23].

\subsection{PGBR Ex Inhibits the Apoptosis-Associated DNA Fragmentation Induced by $\mathrm{H}_{2} \mathrm{O}_{2}$}

DNA fragmentation is a marker of late stage of apoptosis. To verify the possible involvement of apoptosis in the $150 \mu \mathrm{M} \mathrm{H}_{2} \mathrm{O}_{2}$-induced death of neuronal SK-N-SH cells. We investigated its inhibitory effect of PGBR ex on the apoptosis induced by $150 \mu \mathrm{M} \mathrm{H}_{2} \mathrm{O}_{2}$ by observing DNA fragmentation levels in SK-N-SH cells. This figure demonstrates internucleosomal DNA degradation from gel electrophoresis. As a control, we used DNA isolated from untreated cells and no DNA ladder similar results was shown when treated with PGBR ex (Figure 3, lanes $2 \& 3$ ). Fragmented DNA was observed when cells were treated with $150 \mu \mathrm{M} \mathrm{H}_{2} \mathrm{O}_{2}$ resulted in the characteristic apoptotic DNA ladder. DNA fragments smeared the whole lane (Figure 3, lanes 4). These fragmentation patterns are entirely consistent with the molecular weight patterns expected to result from internucleosomal DNA cleavage [24]. But DNA fragments was decreased when co-treated with PGBR ex and $150 \mu \mathrm{M} \mathrm{H}_{2} \mathrm{O}_{2}$ (Figure 3, lanes 5). These DNA fragmentation patterns are entirely consistent with the molecular weight patterns expected to result from internucleosomal DNA cleavage. DNA fragmentations are indicative of early and late stage of apoptosis, respectively. From this results shown that the PGBR ex in our present study showed the anti-apoptotic effect on

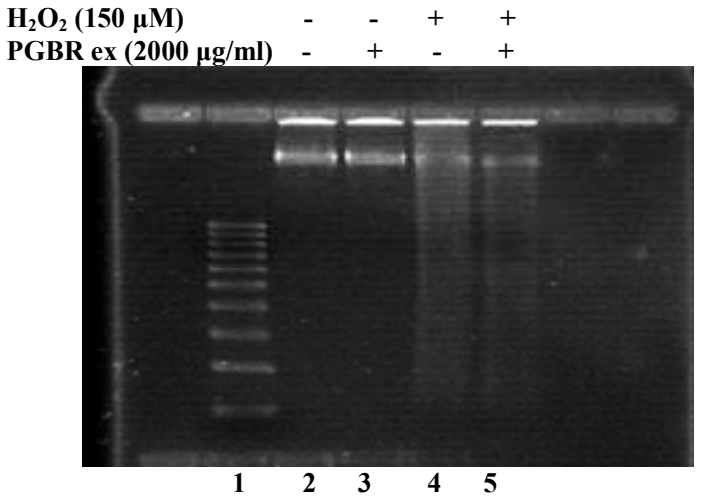

Figure 3. Protective effect of PGBR ex on apoptotic DNA fragmentation in neuronal SK-N-SH cells induced by 150 $\mu \mathrm{m} \mathrm{H}_{2} \mathrm{O}_{2}$. DNA fragmentation was visualized by ethidium bromide and photographed by UV illumination. Marker; lane 1, control (untreated cells); lane 2, PGBR ex; lane 3, $150 \mu \mathrm{m} \mathrm{H}_{2} \mathrm{O}_{2}$; lane 4, PGBR ex and $\mathrm{H}_{2} \mathrm{O}_{2}$; lane 5.

SK-N-SH cells.

\subsection{PGBR Ex Inhibits $\mathrm{H}_{2} \mathrm{O}_{2}$ Induced ROS Generation in Neuronal SK-N-SH Cells}

Intracellular ROS have been implicated with DNA fragmentation and apoptosis [25]. The intracellular radical scavenging activity of a given substance can be evaluated by DCFHDA assay. To determine whether PGBR ex inhibits the ROS generation induced by $150 \mu \mathrm{M} \mathrm{H}_{2} \mathrm{O}_{2}$ in neuronal SK-N-SH cells, and to determine whether the protection of SK-N-SH neuronal cells from apoptosis is accompanied by free radicals scavenging by the PGBR ex, changes in the concentrations of ROS in whole cell suspensions were analyzed over $2 \mathrm{~h}$ period after treatment with PGBR extract and/or $150 \mu \mathrm{M} \mathrm{H} \mathrm{H}_{2} \mathrm{O}_{2}$. SK-N$\mathrm{SH}$ cells showed relatively low levels of basal fluorescence but when treated with $150 \mu \mathrm{M} / \mathrm{ml} \mathrm{H}_{2} \mathrm{O}_{2}$ for $2 \mathrm{~h}$, a marked increase in fluorescence was observed. However, this increase in fluorescence by $150 \mu \mathrm{M} \mathrm{H} \mathrm{H}_{2}$ rapidly returned to the control level in PGBR ex pretreated (2000 $\mu \mathrm{g} / \mathrm{ml}$ ) to the cells (Figure 4).

\section{Conclusions}

The concentrations of GABA in the PGBR ex, BR ex and WR ex were compared with standard pure glutamic acid. The concentration of GABA in the PGBR ex (1200 $\mathrm{nmol} / \mathrm{ml}$ ) was 3 times higher than the GABA concentration in the BR ex $(400 \mathrm{nmol} / \mathrm{ml})$. The concentration of GABA in the PGBR ex was 8 times higher than the GABA concentration in the WR ex $(150 \mathrm{nmol} / \mathrm{ml})$. In this study, we evaluated the effects of PGBR extracts with enhance levels of GABA against $150 \mu \mathrm{M} \mathrm{H}_{2} \mathrm{O}_{2}$ induced cytotoxicity, oxidative stress and apoptosis were compared with those of BR ex, and WR ex on neuronal 


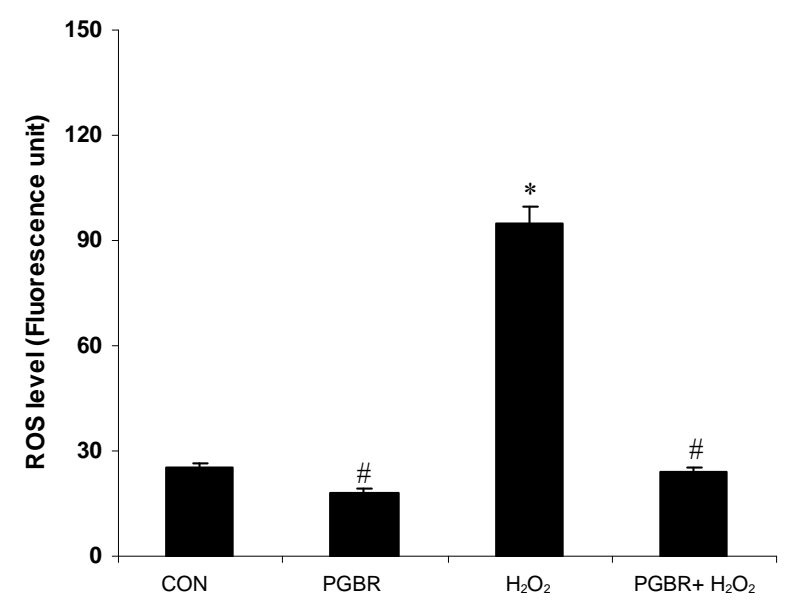

Figure 4. Intracellular ROS level using DCFH-DA assay to measure DCF, which effects ROS level to increase by induction of $150 \mu \mathrm{M} \mathrm{H} \mathrm{H}_{2} \mathrm{O}_{2}$. Protective effects of PGBR ex on ROS generation in neuronal SK-N-SH cells induced by $\mathrm{H}_{2} \mathrm{O}_{2}$. Cells were pre-incubated with PGBR ex $(2000 \mu \mathrm{g} / \mathrm{ml})$ for $3 \mathrm{~h}$, and then added with $150 \mu \mathrm{M} \mathrm{H}_{2} \mathrm{O}_{2}$ for $24 \mathrm{~h}$. DCFHDA (50 $\mu \mathrm{M}$ in final concentration) was then added and incubation was continued for $2 h$. The data shown are means \pm SEM of three experiments performed in triplicate. $*=P<$ 0.05 compared to the untreated control; \# $=P<0.05$ compared to the $150 \mu \mathrm{M} \mathrm{H} \mathrm{H}_{2} \mathrm{O}_{2}$-treated group.

SK-N-SH cells. To our knowledge, this is the first report of the protective effects of PGBR ex on human neuronal SK-N-SH cells.

Natural antioxidants that can neutralize ROS include cysteine, reduced glutathione, polyphenolic compounds carotenoids, ascorbic acid (vitamin C), $\beta$-tocopherol (vitamin E) and indole carbinds. Some researchers have suggested that germination may bring about changes in nutrients and physiologically active substances. During the germination of wheat [26] and Pangium edule Reinw [27] and rice seed vitamin $\mathrm{C}$, vitamin $\mathrm{E}$, ferulic acid, and total phenolic acid contents, alanine and $\beta$-aminobutyrate have been reported to increase significantly [28]. Upon malting of finger millet, changes in both free and bound phenolic acid contents were observed and these reflected their antioxidant properties. We speculate that, during germination, as seed moisture increases, the seed coat has the potential for injury by oxidation and/or microorganism infiltration. Induced saccharolytic enzymes to hydrolyze starch would produce free phenolic compounds having more effective antioxidant activity from hydroxycinnamate sucrose esters. As a result, the content of hydroxycinnamate sucrose esters decreases, whereas that of free phenolic compounds increases. This hypothesis requires verification through further experiments; however, the changes in content and form of phenolic compounds in germinated brown rice suggest that appropriate germination of brown rice may be a method to improve healthrelated benefits.

\section{Acknowledgements}

We are thankful to Dr. Patcharee Tungtrakul Director of Institute of Food Research and Product Development, Kasetsart University, for her advice application of GABA extraction methods. We are deeply Thank Prof. Neelobol Neungton and Assoc. Prof. Dr. Ruchaneekorn W. Kalpravich, Chair of Biochemistry Department, Faculty of medicine, Siriraj hospital, Mahidol University for her kindly encouragement and support throughout this work. We are also thank partum rice milk company and Natural Rice Co. Ltd. For their kindly providing the rice in this research. This work is financially supported by Vejdusit Foundation (Bangkok-Hospital) 2009-2010.

\section{REFERENCES}

[1] C. H. Oh and S. H. Oh, "Effects of Germinated Brown Rice Extracts with Enhanced Levels of GABA on Cancer Cell Proliferation and Apoptosis," Journal of Medicinal Food, Vol. 7, No. 1, 2004, pp. 19-23. doi.10.1089/109662004322984653

[2] S. H. Oh, "Stimulation of Gamma-Aminobutyric Acid Synthesis Activity in Brown Rice by a Chitosan/Glutamic Acid Germination Solution and Calcium/Calmodulin," Journal of Biochemistry and Molecular Biology, Vol. 36, No. 3, 2003, pp. 319-325.

doi.10.5483/BMBRep.2003.36.3.319

[3] S. Y. Latifah, N. Armania, T. H. Tze, Y. Azhar, A. H. Nordiana, S. Norazalina, et al., "Germinated Brown Rice (GBR) Reduces the Incidence of Aberrant Crypt Foci with the Involvement of Beta-Catenin and COX-2 in Azoxymethane-Induced Colon Cancer in Rats," Nutrition Journal, Vol. 9, 2010, pp. 16.

doi.10.1186/1475-2891-9-16

[4] M. E. Gotz, G. Kunig, P. Riederer and M. B. Youdim, "Oxidative Stress: Free Radical Production in Neural Degeneration," Pharmacology \& Therapeutics, Vol. 63, No. 1, 1994, pp. 37-122. doi.10.1016/0163-7258(94)90055-8

[5] J. M. Mates, C. Perez-Gomez and I. Nunez de Castro, "Antioxidant Enzymes and Human Diseases," Clinical Biochemistry, Vol. 32, No. 8, 1999, pp. 595-603. doi.10.1016/S0009-9120(99)00075-2

[6] J. H. Weisburger, "Mechanisms of Action of Antioxidants as Exemplified in Vegetables, Tomatoes and Tea," Food and Chemical Toxicology, Vol. 37, No. 9-10, 1999, pp. 943-948. doi.10.1016/S0278-6915(99)00086-1

[7] C. Behl, "Alzheimer's Disease and Oxidative Stress: Implications for Novel Therapeutic Approaches," Progress in Neurobiology, Vol. 57, No. 3, 1999, pp. 301-323. doi.10.1016/S0301-0082(98)00055-0

[8] J. T. Coyle and P. Puttfarcken, "Oxidative Stress, Glutamate, and Neurodegenerative Disorders," Science, Vol. 262, No. 5134, 1993, pp. 689-695. doi.10.1126/science.7901908

[9] C. Behl, "Vitamin E Protects Neurons Against Oxidative Cell Death in Vitro More Effectively than 17-Beta Estradiol and Induces the Activity of the Transcription Factor 
NF-KappaB," Journal of Neural Transmission, Vol. 107, No. 4, 2000, pp. 393-407. doi.10.1007/s007020070082

[10] R. Zhang, H. Lu, S. Tian, J. Yin, Q. Chen, L. Ma, et al., "Protective Effects of Pre-Germinated Brown Rice Diet on Low Levels of Pb-Induced Learning and Memory Deficits in Developing Rat," Chemico-Biological Interactions, Vol. 184, No. 3, 2010, pp. 484-491.

doi.10.1016/j.cbi.2010.01.043

[11] B. S. Koo, W. C. Lee, K. H. Chung, J. H. Ko and C. H. Kim, "A Water Extract of Curcuma longa L. (Zingiberaceae) Rescues PC12 Cell Death Caused by Pyrogallol or Hypoxia/Reoxygenation and Attenuates Hydrogen Peroxide Induced Injury in PC12 Cells," Life Science, Vol. 75, No. 19, 2004, pp. 2363-2375. doi.10.1016/j.1fs.2004.07.003

[12] P. B. Godkar, R. K. Gordon, A. Ravindran and B. P. Doctor, "Celastrus Paniculatus Seed Water Soluble Extracts Protect Against Glutamate Toxicity in Neuronal Cultures From Rat Forebrain," Journal of Ethnopharmacology, Vol. 93, No. 2-3, 2004, pp. 213-219. doi.10.1016/j.jep.2004.03.051

[13] E. M. A., A. Nomura, K. Koshimuzu, H. Ohigashi, K. Mizuno and T. Taniguchi, "Synthesis of FeruloylmyoInositols and Their Inhibitory Effects on Superoxide Anion Generation," Bioorganic \& Medicinal Chemistry Letters, Vol. 10, 2000, pp. 1439-1442. doi.10.1016/S0960-894X(00)00252-3

[14] H. I. Ichikawa, B. Xu, Y. Yoshii, M. Nakajima and T. Konishi, "Antioxidant Activity of Anthocyanin Extract from Purple Black Rice," Journal of Medicinal Food, Vol. 4, No. 4, 2001, pp. 211-218. doi.org/10.1089/10966200152744481

[15] H. S. Chung and W. S. Woo, "A Quinolone Alkaloid with Antioxidant Activity from the Aleurone Layer of Anthocyanin-pigmented Rice," Journal of Natural Products, Vol. 64, No. 12, 2001, pp. 1579-1580. doi.10.1021/np010324g

[16] S. Toyokuni, T. Itani, Y. Morimitsu, K. Okada, M. Ozeki, S. Kondo, et al., "Protective Effect of Colored Rice over White Rice on Fenton Reaction-Based Renal Lipid Peroxidation in Rats," Free Radical Research Communicaitions, Vol. 36, No. 5, 2002, pp. 583-592. doi.10.1080/10715760290025960

[17] J. W. C. Hyun and H. S. Cyanidin, "Cyanidin and Malvidin from Oryza sativa cv. Heungjinjubyeo Mediate Cytotoxicity Against Human Monocytic Leukemia Cells by Arrest of G(2)/M Phase and Induction of Apoptosis," Journal of Agricultural and Food Chemistry, Vol. 52, 2004, pp. 2213-2217. doi.10.1021/jf030370h

[18] C. Z. Hu, W. Ling and D. D. Kitts, "Black Rice (Oryza sati Va L. indica) Pigmented Fraction Suppresses Both Reactive Oxygen Species and Nitric Oxide in Chemical and Biological Model Systems," Journal of Agricultural Food Chemistry, Vol. 51, 2003, pp. 5271-5277. doi.10.1021/jf034466n
[19] W. Weecharangsan, P. Opanasopit, M. Sukma, T. Ngawhirunpat, U. Sotanaphun and P. Siripong, "Antioxidative and Neuroprotective Activities of Extracts from the Fruit Hull of Mangosteen (Garcinia mangostana Linn.)," Medical Principles and Practice, Vol. 15, No. 4, 2006, pp. 281-287. doi.10.1159/000092991

[20] K. Higashi-Okai, K. Kanbara, K. Amano, A. Hagiwara, C. Sugita, N. Matsumoto, et al., "Potent Antioxidative and Antigenotoxic Activity in Aqueous Extract of Japanese Rice Bran-Association with Peroxidase Activity," Phytotherapy Research, Vol. 18, No. 8, 2004, pp. 628-633. doi.10.1002/ptr.1576

[21] H. Wang and J. A. Joseph, "Quantifying Cellular Oxidative Stress by Dichlorofluorescein Assay Using Microplate Reader," Free Radical Biology \& Medicine, Vol. 27, No. 5-6, 1999, pp. 612-616. doi.10.1016/S0891-5849(99)00107-0

[22] D. Schubert, C. Behl, R. Lesley, A. Brack, R. Dargusch, Y. Sagara, et al., "Amyloid Peptides are Toxic via a Common Oxidative Mechanism," Proceedings of the National Academy of Sciences USA, Vol. 92, No. 6, 1995, pp. 1989 1993. doi.10.1073/pnas.92.6.1989

[23] J. J. Yan, J. Y. Cho, H. S. Kim, K. L. Kim, J. S. Jung, S. O. Huh, et al., "Protection Against-Amyloid Peptide Toxicity in Vivo with Long-Term Administration of Ferulic Acid," British Journal of Pharmacology, Vol. 133, No. 1, 2001, pp. 89-96. doi.10.1038/sj.bjp.0704047

[24] G. R. Bicknell, R. T. Snowden and G. M. Cohen, "Formation of High Molecular Mass DNA Fragments Is a Marker of Apoptosis in the Human Leukaemic Cell Line, U937," Journal of Cell Science, Vol. 107, 1994, pp. 24832489.

[25] B. C. Scott, O. I. Aruoma, P. J. Evans, C. O’Neill, A. Van der Vliet, C. E. Cross, et al., "Lipoic and Dihydrolipoic Acids as Antioxidants. A Critical Evaluation," Free Radical Research, Vol. 20, No. 2, 1994, pp. 119-133. doi.10.3109/10715769409147509

[26] F. Yang, T. K. Basu and B. Ooraikul, "Studies on Germination Conditions and Antioxidant Contents of Wheat Grain," International Journal of Food Sciences and $\mathrm{Nu}$ trition, Vol. 52, No. 4, 2001, pp. 319-330. doi.10.1080/09637480120057567

[27] N. Andarwulan, D. Fardiaz, G. A. Wattimena and K. Shetty, "Antioxidant Activity Associated with Lipid and Phenolic Mobilization during Seed Germination of Pangium Edule Reinw," Journal Agricultural and Food Chemistry, Vol. 47, No. 8, 1999, pp. 3158-3163. doi.10.1021/jf981287a

[28] S. Tian, K. Nakamura and H. Kayahara, "Analysis of Phenolic Compounds in White Rice, Brown Rice, and Germinated Brown Rice," Journal Agricultural and Food Chemistry, Vol. 52, No. 15, 2004, pp. 4808-4813. doi.10.1021/jf049446f 